TITLE:

\title{
Shell Effect on the Energy Dependence of the Nuclear Level Density(Abstract_要旨)
}

$\operatorname{AUTHOR}(S):$

Maruyama, Michio

\section{CITATION:}

Maruyama, Michio. Shell Effect on the Energy Dependence of the Nuclear Level Density. 京 都大学, 1970, 理学博士

ISSUE DATE:

1970-01-23

URL:

http://hdl.handle.net/2433/213311

RIGHT: 


\section{【 77 】}

氏名热㟧倫站

学位の種類理学博士

学位記番号論 理 博 第 292 号

学位授与の日付 昭 和 45 年 1 月 23 日

学位授与の要件学位 規則第 5 条第 2 項該当

学位論文題目 Shell Effect on the Energy Dependence of the Nuclear

Level Density

（原子核レベル分布密度のエネルギー依存性に現われる殼効果）

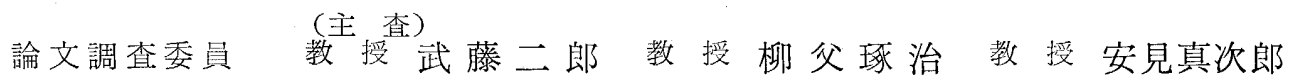

\section{論交内容の要旨}

原子核の準位密度については，ベーテによって自由ガス模型が導入されて以来，いくつかの理論的模型 が提出されているが，中であ，フェルミ・ガス模型が原子核の問題を諭ずるときに最もよく用いられてい る。この理論によれば，原子核の励起エネルギーEにおける準位密度 $\rho(\mathrm{E})$ は

$$
\rho(\mathrm{E})=\mathrm{E}^{-2} \exp [2 \sqrt{\mathrm{aE}}]
$$

の形で与えられる。一方, 実験的に種々の核について, 種々の反応を測定するととによって準位密度の実 測が行なわれて扣り，その多くはこのフェルミ・ガス型によく合うとされているが，中には，核を熱力学 的に取扱って得られる温度を $\mathrm{T}$ るるとき， $\rho(\mathrm{E})=\exp \mathrm{E} / \mathrm{T} 〕 の$ 形をとる，いわゆる定温度型の式に合 うとされるものもある。

申請者は原子核の準位密度の分布型が原子核の質量数 A と共にどのように变化するかを，多くの核につ いて系統的に同一実験条件の下に測定し，乙れらの分有型の変化が原子核の殻構造と強く関連しているこ とを示すのに成功した。

申請者は日本原子力研究所のバン・デ・グラーフから得られる中性子を用いて，その原子核による90 方向への非弾性散乱を測定し，散乱中性子のエネルギースペクトル $N\left(E_{n}\right)$ を飛行時間法によって求め た。入射中性子のエネルギーは $3.57 \mathrm{MeV}$ から $8.52 \mathrm{MeV}$ にいたる10種のエネルギーにわたり，調べた原 子核は Co, Ni, Cu, As, Br, Sr, Y, Nb, Ag, In, Sn, Sb, I, Cs, Ba, La, Ce, Pr, Ho, Ta, $\mathrm{Au}, \mathrm{Bi}$ の22元素で，原子番号27から83にわたっている。

核反応の複合核過程に対する統計理論によれば, $N\left(E_{\mathbf{n}}\right)$ と $\rho(\mathrm{E})$ との間には

$$
\mathrm{N}\left(\mathrm{E}_{\mathrm{n}}\right)=\text { const } \cdot \mathrm{E}_{\mathbf{n}} \cdot \sigma_{\mathrm{c}}\left(\mathrm{E}_{\mathrm{n}}, \mathrm{E}\right) \cdot \rho(\mathrm{E})
$$

の関係がある。 $\sigma_{\mathrm{c}}\left(\mathrm{E}_{\mathrm{n}}, \mathrm{E}\right)$ 即ちエネルギー $\mathrm{E}_{\mathrm{n}}$ の中性子の吸収断面積は昨に多くの測定值があるので，乙 れによって $\rho(\mathrm{E})$ を求めるととができる。申請者は各原子核について，10種のエネルギーについて導出さ れた10個の $\rho(\mathrm{E})$ を最少自乘法によって重冨し，それぞ机原子核について励起エネルギーが $2.5 \mathrm{MeV}$ 
ら $7.5 \mathrm{MeV}$ の範囲にわたり $\rho(\mathrm{E})$ を確定した。

その結果, $\mathrm{Co}, \mathrm{Cu}, \mathrm{As}, \mathrm{Br}, \mathrm{Ag}, \mathrm{I}, \mathrm{Ho}, \mathrm{Ta}, \mathrm{Au} の 9$ 例 (第一群)についてはフエルミ・ガス型; $\mathrm{La}, \mathrm{Ba}, \mathrm{Ce}, \operatorname{Pr} 4$ 例 (第二群)については定温度型；In，Sn，Sb，Cs の4例（第三群）は複合型； Ni， $\mathrm{Sr}, \mathrm{Br}$ の 3 例 (第四群) はコンケイブ型（横軸に $\mathrm{E}$, 縦軸に $\rho(\mathrm{E})$ の対数をとるとき上元に四になる) であるととがわかった。

これら準位密度の分布型の異なる原子核の群を，原子核の殻模型の観点から跳めると，核を構成する陽 子 $(\mathrm{Z})$ ，中性子(N)の数が，それぞれ，いわゆる閉殼を形成する数（魔法数）から遠いか近いかに関係し て群を構成している。即ち，第四群は複閉殼（N，Z共に魔法数）に近い核，第三群は陽子閉殼に近い 核，第二群は中性子閍殼の核であり，第一群は閉殼から遠い核である。これらのととは集位密度分有の型 がその核の殼構造に強く関連しているととを暗示している。

そてで申請者は中性子，陽子の数が魔法数 $N=82, N=126$ に近い核について，実験によって確立され ている準位データを援用しつつ，原子核の殼模型から導き出される励起準位を一つ一つ人為的に算出する 作業を電子計算機によって遂行し，殸模型の立場での，いわば理論的準位密度分布というべきする求め た。との作業の結果は申請者が実験的に得た準位密度分布と極めてよい一致を示すととが明らかとなっ た。そこで申請者は準位密度分布の型と殼模型との関連性を整理した結果，準位密度分布のタイプはその 核の基底状態に招ける殼の充足度，(陽子系，中性子系のそれぞれについて，殼模型で現われる広いエネ ルギー・ギャップの上下にある粒子数とホール数の和）と強く関連していることを見出し，陽子充足度と 中性子充足度とをそれぞれ座標軸にとったとき，準位分布の4 種のタイプがその図上のどの範国に現われ るかを定性的に示すととに成功したのである。

\section{論文審查の結果の要旨}

原子核には多くの励起準位があるが，準位の数は一般に励起エネルギーの高い程多くなり，その準位間 隔は小さくなる。原子核のエネルギー準位密度の分布を，個々の原子核の個性をはなれて大局的に説明す る理論としては，原子核を陽子と中性子の気体球と考え，核子を狭い空間に閉じ込められた互いに相互作 用のほとんどない自由粒子として取扱う，いわゆるフェルミ・ガス模型があり，この取扱いで理論的に導 かれる励起準位函数は多くの場合, 実測値己一致するとされてきた。ただし, 多くの核の中には, この函 数と一致しない例もいくつか知られていたが，理論の明析さにおいて，大局的には正しいものとされてき ている。

申請者は多くの核について，その準位密度分布を系統的に実測し，それらの型が 4 㮔に分類されること を示し，そのちがいが，原子核の殼構造に由来するものであるととを示すのに成功した。

甲請者は極めて慎重な実験的配慮の下にコバルトからビスマス（原子番号27から83）に至る22種の原子 核について，その核による中性子非弾性散乱の実験を行ない，まず散乱中性子のエネルギー分有を飛行時 間法によって求めた。とのエネルギー分布から, 既知の中性子捕獲断面積を用いて原子核の準位密度函数 $\rho(\mathrm{E})$ を求めるのであるが，その際にあ，入射エネルギーによる変化，採用すべき断面積のちがいなどに ついて慎重な榆討を加え，極めて信頼性の高い $\rho(\mathrm{E})$ の形を各原子核について実験的に定めることに成功 
した。

申請者はこれら多くの核種について $\rho(E)$ の形を調查し, それらが 4 種類のタイプ, 即ち, フェルミ・ ガスモデル型, 定温度型, 複合型, コンケイブ型の 4 種に分類され得るととを見出した。しかすとの 4 種 の分類に入るそれぞれの原子核は，その核を殼模型（shell model）の钼点からみたとき，その原子核の陽 子数 (Z) 招よび中性子数 (N) が，それぞれ，いわゆる魔法数（magic number）に近いか遠いかによ って分かれていることを見出した。申請者はこの $\rho(\mathrm{E})$ の型と殸模型との関連性を一層確実なものとする ために，殽模型の立場からそれぞれの核について凡ゆる可能な励起準位を電算機を用いて数え上げる作業 を行ない，款模型に基づく推計汧起準位密度とも呼ぶべき理論的密度分存を作成し，乙の分布と実測によ る分布との比較を試みて極めてよい一致の得られることを見出した。このように，個々の核について広い 励起エネルギーの範囲にわたって可能な準位の数を数值的に数え上げた例は今までになく，申請者が初め て行なったととである。このような励起準位函数のタイプと殼模型との関連性について申請者は更に考察 を進め，原子核の基底状態に抢ける陽子，中性子のそれぞれの款充足度（陽子，中性子について，それぞ れの閉殸の上下に存在する粒子数とホール数の和を与える数值）の数值の組み合せがそれぞれの核の準位 密度分布のタイプと強い対応関係にあるととを示すととに成功した。

原子核を気体球として取扱うフェルミ・ガス模型と, 個々の核内核子の軌道を考える殼模型とは元来, 極めて異なる観点から提起された原子核模型であって, 励起準位の密度について殼模型の観点からこのよ うな分析の行なわれた例はない。申請者の論文は広い範囲の多くの原子核についてその励起準位密度函数 の信頼性ある実測值を与えると共に，とれらの準位密度函数の形が原子核の殼構造と深い関連をもつこと を示すととによって，原子核物理学の分野に新しい知見を加え，新しい問題を投げかけたものといってよ く, 理学博士の学位論文として充分価值のあるあのと認める。 